\title{
SOCIAL HETEROGENEITY AND CHILDREN'S NUTRITION IN THE RURAL ENVIRONMENT
}

\author{
Livia Rocha ${ }^{1}$ \\ Tatiana Engel Gerhardt ${ }^{2}$ \\ Daniel Labernarde dos Santos ${ }^{3}$
}

Rocha L, Gerhardt TE, Santos DL. Social heterogeneity and children's nutrition in the rural environment. Rev Latino-am Enfermagem 2007 setembro-outubro; 15(número especial):828-36.

Objectives: this study is inserted in an Interdisciplinary Program of Research and aims to learn about the nutritional situation and life context of children under five in the rural environment of Arambaré/RS, Brazil, through an epidemiological cross-sectional descriptive study. Method: the data of anthropometrical assessment (Weight/Age, Age/Height, Weight/Height) expressed in Z scores, whose reference population is that of the National Center for Health Statistics (NCHS) were analyzed in the Epinut software, and the semi-structured form applied to the child's responsible was analyzed through descriptive statistics in the Epi-Info 6.04. Results: It is evidenced that the nutritional problems vary within the social heterogeneity present in the municipality. There are different levels of vulnerability to illness. Conclusion: this study demonstrates the importance of understanding the social dynamics modelling individual behavior that reflects on health.

DESCRIPTORS: child nutrition disorders; social conditions; rural population; rural health

\section{LA HETEROGENEIDAD SOCIAL Y LA NUTRICIÓN INFANTIL EN EL MEDIO RURAL}

Objetivos: El estudio se inserta en un Programa Interdisciplinar de Investigación y objetiva conocer la situación nutricional y el contexto de vida del universo de niños menores de cinco años del medio rural de Arambaré/ RS, Brasil, a través de un estudio epidemiológico del tipo seccional descriptivo. Métodos: Los datos de la evaluación antropométrica (peso/edad, edad/estatura, peso/estatura) fueron analizados en el Epinut, y los del formulario semiestructurado aplicado al responsable del niño fueron analizados vía estatística descriptiva en el Epi-info 6.04. Resultados: Se constata que los problemas nutricionales varían dentro de la heterogeneidad social presente en el municipio, lo que representa diferentes grados de vulnerabilidad al adolecimiento. Conclusiones: Se demostró la importancia de comprender las dinámicas sociales que modulan los comportamientos de los individuos y repercuten sobre su salud.

DESCRIPTORES: trastornos de la nutrición del niño; condiciones sociales; población rural; salud rural

\section{A HETEROGENEIDADE SOCIAL E A NUTRIÇÃO INFANTIL NO MEIO RURAL}

Objetivos: o estudo insere-se num Programa Interdisciplinar de Pesquisa e objetiva conhecer a situação nutricional e o contexto de vida do universo de crianças menores de cinco anos do meio rural de Arambaré/RS, Brasil, por meio de um estudo epidemiológico do tipo seccional descritivo. Métodos: os dados da avaliação antropométrica (peso/idade, idade/estatura, peso/estatura) expressos em escore $z$, como população de referência a do National Center for Health Statistics (NCHS), foram analisados no Epinut, e os do formulário semi-estruturado aplicado ao responsável da criança, foram analisados via estatística descritiva no Epi-info 6.04. Resultados: constata-se que os problemas nutricionais variam dentro da heterogeneidade social presente no município o que representa diferentes graus de vulnerabilidade ao adoecimento. Conclusões: este estudo demonstra a importância de compreender as dinâmicas sociais que modulam os comportamentos dos indivíduos e repercutem sobre sua saúde.

DESCRITORES: transtornos da nutrição infantil; condições sociais; população rural; saúde rural

${ }^{1}$ M.Sc in Nursing, Professor, Universidade Regional Integrada do Alto Uruguai (URI) Campus Santiago, RS, Brasil, e mail: rochalilica@yahoo.com.br; ${ }^{2}$ PhD in Antropology, Professor Rio Grande do Sul Federal University, RS, Brazil, e mail: tatiana.gerhardt@ufrgs.br; ${ }^{3}$ Master Student, Rio Grande do Sul Federal Uniiversity, RS, Brasil, e-mail: daniel.Isantos@pop.com.br 


\section{INTRODUCTION}

$\boldsymbol{F}_{\text {ood and nutrition are fundamental for health }}$ promotion and protection, which permit full human growth and development potential, with quality of life and citizenship $^{(1)}$. Therefore, for many scholars $^{(2-4)}$, diagnosing and supervising children's nutritional condition is a practical and sensitive way to evaluate health conditions and tendencies.

Evaluations of children's nutritional state have become a widespread practice in various countries due to the need to identify nutritional problems and thus prevent negative repercussions on their health. As far as Brazil is concerned, there is a certain consensus about its relevance. In fact, it is an action recommended by the Ministry of Health, developed by teaching and research institutions, in addition to non governmental organizations.

In Brazil, nutritional surveillance has been contemplated in the third guideline of the National Food and Nutrition Policy. It consists of a strategy recommended by WHO, PAHO, FAO and UNICEF, through actions of the Information System of Food and Nutritional Surveillance (ISFNS), aimed at monitoring the conditions of unprivileged risk population groups and providing a quick and permanent evaluation method of all factors influencing food consumption and nutritional state levels, with a view to improving Brazilian population's health and nutrition"(5). To reach this goal, nutritional state surveillance should be a practice developed in the primary health care service network and incorporated into care routines ${ }^{(6)}$.

The Brazilian population deals with various nutritional problems. Many are difficult to evaluate on a large scale, because they demand laboratory analysis (like vitamin and mineral deficiencies). On the other hand, malnutrition and overweight/obesity diagnoses gain emphasis and investigation prerogative on a national level because they are simple to identify; using simple actions, such as following growth: weight and height (anthropometrical data) analysis ${ }^{(7)}$.

The apparently opposite genesis between the two problems, one due to excessive and the other to deficient food consumption, has been broadly discussed in literature. Research shows that, in poorer families where obesity has considerably increased, the presence of both nutritional problems can be considered the result of a common cause: food insecurity. Researchers state that the quality and quantity of food these individuals consume cause the so-called "malnourished obesity". They believe that economic limitations can lead to the consumption of food rich in sugar and starches, which, apart from not satiating hunger and nutritional necessities, fatten ${ }^{(7-}$ 8). These statements are interesting, but require care when used as an explanation hypothesis for phenomena in every context ${ }^{(9)}$.

In addition to the complexity of problems involving nutritional deprivation and excess, arrangements and combinations between them, in the most diverse realities, seem to illustrate the tangle of elements that need to be revealed before planning any intervention.

Without ignoring the contribution of the economic factor in the various nutritional situations found in the same social stratum or similar geographical area, there is a hypothesis that individuals and families create different and innumerable strategies, in a way that, despite being in the midst of economic limitations, they succeed in guaranteeing and facilitating their members' full growth and development ${ }^{(9)}$.

This idea reports to the definition of "Life situation", regarded as ${ }^{(9)}$ the use that social actors make of their material and immaterial conditions (in accordance with their perceptions about the adversities they are submitted to, while they recompose and reinterpret them). In addition, "this notion has the merit to permit a synthesis between what, in the individual's or group's existence, regards contextual coercive factors (material, social or cultural), and the interpretations and combinations that individuals makes. This would be in accordance with their own perceptions, aims and capacity to formulate a life project; modulating, for example, different degrees of vulnerability to illness"(9).

Results from studies ${ }^{(10-14)}$ about child nutrition and rural populations exemplify the importance of appropriation and planning based on a more limited reality. Despite their scarcity, and though they exclusively analyze the nutritional deficit, these studies show that high malnutrition rates are not ubiquitous throughout the rural setting. Each environment has its singular characteristics, possibly modulated by social actions, which reflect their own results and portray the country's regional heterogeneity.

Several studies have been carried out in different Brazilian states (Alagoas ${ }^{(10)}$, Minas Gerais ${ }^{(11)}$, Rio de Janeiro ${ }^{(12)}$, Rio Grande do Sul ${ }^{(13)}$ and Parana $\left.{ }^{(14)}\right)$, 
and their results show that each study presents a conjuncture specific to historical and spatial (regional differences) moments, in addition to social heterogeneity. Moreover, through these differences, the close relationship between access to services and better health conditions can be illustrated, in this case, rural children's nutritional health.

Therefore, there seems to be a growing need to consider the issues involving health and rural populations. Within this aspect, and in agreement with the theme of this study, child nutrition stands out as an important public health issue in these contexts and, thus, deserves attention in governmental, teaching, research and health care domains.

Supported by these questions, this study sought to learn about children's nutritional situation and life context in the rural area of Arambaré/RS, Brazil. This study was developed within the Interdisciplinary Research Program entitled "Agriculture evolution and differentiation, rural environment transformation and sustainable development in costal plain and southern plateau municipalities of Rio Grande do Sul: an interdisciplinary approach" (POINTER) ${ }^{(15)}$, result of Franco-Brazilian inter-universities cooperation ${ }^{(15-16)}$.

The study was carried out in the southern half of Rio Grande do Sul, more precisely in eight municipalities (Arambaré, Camaquã, Canguçu, Chuvisca, Cristal, Santana da Boa Vista and São Lourenço do Sul), whose characteristics and interrelations showed to be pertinent to the study aims. Taking into account the innumerable elements that characterize the empirical areas that inter-relate in a dynamic way, a sectorial or unilateral focus would not be sufficient to comprehend this complex reality. Therefore, the interdisciplinary approach emerges as a scientific demand to analyze these complex realities, which allows for the production of knowledge based on the different subjects' interfaces.

The health area contributes with the identification of health-disease process determinants, in the dynamics of local realities and in the production of analyses, with the other areas, about the region's rural development, its characteristics and the most recent deadlock ${ }^{(15)}$. It is based on approaching the interfaces between public health and anthropology regarding social disparities in the rural environment. In this sense, it permits to analyze the existing social disparities, taking into account material determinants as well as health regulation and difficulty mechanisms, which have social and cultural origins, and also the role of social relations and the consequences of individual behavior in relation to body disorders and health care service structure ${ }^{(9)}$.

Based on this interface, health departments establish their focus on the population's most fragile groups, since they are the most prone to social and economic conditions that interfere with the healthdisease process, and thus determine the need for more attention and investment in public policies. This is the case of children, for example. In a special phase of vulnerability, they need specific actions and constant monitoring of their growth and development.

Among the eight municipalities of the POINTER empirical area, Arambaré was the target of this study due to the lack of information (secondary data) about the nutritional situation and the apparent disregard of public child health policies. Moreover, the analysis of the municipality's particularities showed that social diversities and complex dynamics reproduced themselves at a more intrinsic level in the rural environment, thus becoming fertile ground to carry out an analysis of the nutritional issue within a broader view regarding social diversities.

\section{METHOD}

The present study is an epidemiological perspective of a sectional, exploratory and descriptive type. The study population consisted of the universe of children aged under five in the rural environment of Arambaré/RS, Brazil (determined based on IBGE census tract levels). This population was identified through the Local Family Register, used by community health agents, and by actively investigating each home in areas that were not covered by health agents. The total number of children in this age group was eighty one (81), however, one child was excluded from this study, so that eighty (80) children were investigated.

Data collection regarding child and family context, as well as children's anthropometric evaluation, occurred through a house-to-house inquiry, which took place during July and August 2005. The researchers counted on the help of community health agents during field work to locate the children and give instructions in the rural environment.

To obtain the information, a form containing semi-structured questions was applied to the child's mother or responsible adult. This data collection 
instrument was made up of a series of variables proposed by authors who carry out the same thematic research(2). Data were analyzed through descriptive statistics. After being coded, the data was inserted into a database created with Epi-info 6.04. It is important to point out that data concerning children and families was analyzed in different databases, so that there was no duplicity of answers in the case of families with more than one child.

Anthropometrical measurements were carried out following standardized norms. It is important to note that the height of children younger than two was taken with the children lying down, using an anthropometrical wooden ruler (infantometer); children older than two were measured with a metric tape fixed to a flat wall with no baseboard, but with the help of a frame; in this case, children stood up, barefoot, with both heels together and their knees straight. To check their weight, a portable digital scale was used with a maximum capacity of $150 \mathrm{Kg}$ and precision of $100 \mathrm{~g}$. Small children were weighed on their mothers' lap and the maternal weight reduced from the total. Every child was weighed with the minimum amount of clothes possible, so there would be no interference in the real weight.

The nutritional evaluation was carried out using EPINUT, which uses the National Center for Health Statistics (NCHS/1977) reference. Each child was assessed in terms of anthropometrical indexes: weight/age (W/A), weight/height $(W / H)$ and height/ age $(H / A)$. Children's nutritional state was classified using the cut-off points expressed in z-score.

The standard deviation (SD) means that the obtained data is distant from the reference median and follows $\mathrm{WHO}$ recommendations ${ }^{(17)}$. The following was considered: $z$-score below- $3 S D$ indicates severe malnutrition; z-score between - 2.9 SD and - 2 SD indicates moderate malnutrition; z-score between 1.9 SD and - $1 S D$ indicates risk for malnutrition or slight malnutrition; z-scores above - 1 SD and below $+1 S D$ indicate eutrophic; z-scores above + $1 S D$ indicate overweight or risk for obesity (only for the $W / A$ and $W / H$ indexes); $z$-scores above $+2 S D$ indicate (only for the W/A and $\mathrm{W} / \mathrm{H}$ indexes).

In order to characterize the social diversity present in the rural environment and identify the children's nutritional situation in each group, the results were discussed based on a representative typology of local social heterogeneity, constructed based on the property's land structure and on the type of relation the family constructed with it.
This characterization resulted in five types: $57.7 \%$ (41 families and 44 children) are employed on large properties, $23.9 \%$ (14 families and 17 children) smallholding owners, $15.5 \%$ (11 families and 12 children) squatters, $4.2 \%$ ( 3 families and 3 children) salaried workers on small properties and $2.8 \%$ (2 families and 4 children) irregular rural inhabitants. For the classification of small and large properties, the definition from the fiscal module was used, which is the measurement unit expressed in hectares, fixed for each municipality based on various aspects according to the Land Statute.

Special care was taken in relation to the ethical aspects involving studies with human beings, as recommended by National Health Council resolution $196 / 96$, issued on October $10^{\text {th }} 1996$. The project was sent to and approved by the UFRGS Research Ethics Committee on July $26^{\text {th }} 2005$.

\section{ANALYSIS AND RESULT DISCUSSION}

During data collection and analysis, it became evident that, in Arambaré, there is a heterogeneous rural society, in which very distinct social groups coexist in terms of their origin, their connection with the land, as well as the socioeconomic situation encountered. Correspondingly, the strategies and forms of biological and social reproduction presented by these social groups should also be diverse.

The identified social groups are classified as follows: Salaried workers on small properties, almost always working in the function of smallholding managers, enjoying the benefits of the property, having access to good living conditions, sanitation and durable consumer goods, subsisting by growing vegetables and animals; Employed on large properties, families that reside and work on large lands intended for rice culture and/or cattle raising, most enjoy good living and sanitary conditions, more than half the families do not produce anything, and those that do only produce for their own consumption; Smallholding owners, families that reside on small allotments, more than half of them develop insignificant family agriculture and/or raise animals (chickens, pigs, milk cows), both for subsistence, and the rest produce nothing. Some families live of informal, sporadic work and in precarious conditions: the houses are small with a very bad infrastructure, almost half of them without tap water and sanitation; 
Squatters, there are three squats in the municipality that house families associated with the Movimento Sem Terra [Without Land Movement]. Within and between each, there is socioeconomic diversity; Irregular rural inhabitants, families that reside irregularly on a piece of land located between the road and the fence that divides properties, creating real "rural shanty towns". These families survive from sporadic work and raise animals exclusively for their own use (milk cows or chickens). One of the families does not have electricity and neither family has tap water or installed sanitation.

Within this social heterogeneity represented by five types of properties, the diversity in the distribution of nutritional problems could be verified, since these different types of malnutrition and excessive weight problems varied. It is believed that such a variation is a result of subjects' social performance in the construction of strategies and alternatives to solve material and immaterial problems that influence and mark individuals' life and health conditions.

Analyzing the studied children's sociodemographic variables, it was found that only the smallholding owners had a higher percentage of boys. Regarding the children's age group, most $(70.1 \%)$ were two years or older.

In order to facilitate the comprehension and analysis of the results concerning the nutritional situation of the studied universe and the typology, three tables are presented (tables 1, 2, and 3 ), each regarding one of the three anthropometrical indexes.

According to the data presented in the three tables below, it can be confirmed, in general terms, that the nutritional state of children in the rural environment of Arambaré follows the tendencies in Brazil regarding malnutrition, since the higher frequency is of low height for age $(7.6 \%)$, followed by low weight for age (5.1\%) and, lastly, low weight for height (3.9\%). Obesity is present, but with low prevalence; and overweight, in the weight/height index, slightly exceeds (5.3\%) the percentage expected in healthy populations.

Regarding the nutritional deficit, between the three degrees of problem severity, mild cases or risk for malnutrition prevail in the three studied anthropometrical indexes. In spite of these results being difficult to compare, since the majority of studies only consider established malnutrition (z score less than - 2 , or the sum of moderate and serious cases), it does permit the early detection and intervention of the disease, minimizing or impeding its negative evolution.

The isolated content analysis revealed that the weight/height index (Table 1), which characterizes acute malnutrition cases, shows a prevalence of $3.9 \%$ (z score less than -2 , or moderate and serious cases). This result is high if compared to the data found in the last populationbased research in Brazil about child nutrition, the National Demographic and Health Research (Pesquisa Nacional Demografia e Saúde - PNDS) of 1966 , in which the rates among children in southern (urban areas) and rural regions in Brazil were $0.8 \%$ and $2.6 \%$, respectively ${ }^{(18)}$. The distribution of these indexes among the five types of properties shows that, of the three cases that characterize this deficit, two were found among smallholding properties and one among squatters.

Table 1 - Children's nutritional state in the rural environment of Arambaré, according to the Weight/Height indicator and the type of property the family lives in, 2005

\begin{tabular}{|c|c|c|c|c|c|c|c|c|c|c|c|c|}
\hline \multirow{2}{*}{ W/H Index } & \multicolumn{2}{|c|}{ Total population } & \multicolumn{2}{|c|}{$\begin{array}{l}\text { Employed on Large } \\
\text { Properties }\end{array}$} & \multicolumn{2}{|c|}{$\begin{array}{l}\text { Salaried Workers on } \\
\text { Small Properties }\end{array}$} & \multicolumn{2}{|c|}{ Squatters } & \multicolumn{2}{|c|}{ Smallholding owners } & \multicolumn{2}{|c|}{$\begin{array}{c}\text { Irregular rural } \\
\text { inhabitants }\end{array}$} \\
\hline & $\mathbf{N}$ & $\%$ & $\mathbf{N}$ & $\%$ & $\mathbf{N}$ & $\%$ & $\mathbf{N}$ & $\%$ & $\mathbf{N}$ & $\%$ & $\mathbf{N}$ & $\%$ \\
\hline Serious malnutrition* & 1 & 1.3 & - & - & - & - & - & - & 1 & 5.9 & - & - \\
\hline Moderate Malnutrition* & 2 & 2.6 & - & - & - & - & 1 & 8.3 & 1 & 5.9 & - & - \\
\hline Slight Malnutrition & 6 & 7.5 & 4 & 9.1 & - & - & - & - & 2 & 11.8 & - & \\
\hline Eutrophic & 55 & 68.8 & 30 & 68.2 & 2 & 66.7 & 10 & 83.3 & 9 & 52.9 & 4 & 100 \\
\hline Overweight & 15 & 18.8 & 10 & 22.7 & 1 & 33.3 & 1 & 8.3 & 3 & 17.6 & - & - \\
\hline Obesity & 1 & 1.3 & - & - & - & - & - & - & 1 & 5.9 & - & - \\
\hline Total & 80 & 100 & 44 & 100 & 3 & 100 & 12 & 100 & 17 & 100 & 4 & 100 \\
\hline
\end{tabular}

Source: ROCHA, L; SANTOS, D.L; GERHARDT, T.E; direct research, Arambaré, 2005

* The sum of serious and moderate malnutrition ( $z$ score less than - 2 ) indicates established cases of the disease, and this rate for the total population represents $3.9 \%$. 
Chronic malnutrition (considering z scores under -2 , or moderate and serious cases), represented by short height for age (Table 2), was present in $7.6 \%$ of children. This prevalence is low if compared with the prevalence between children younger than five from rural Brazil (19.0\%) and total Brazil (including children from rural and urban areas) (10.5\%), according to the 1996 PNDS data.

Nevertheless, when confronting the results of these indexes with the rural and urban southern region of the country, the $7.6 \%$ found in Arambaré was much higher than the $5.1 \%$ identified in the Southern region ${ }^{(18)}$.

Once again, the distribution among the five types of properties the families are inserted in showed that moderate malnutrition in this index is found in the smallholding owners' properties, but it is also present among squatters and irregular inhabitants. It is important to emphasize that, regarding the latter type, four of the studied children presented some degree of height problems, as shown in Table 2.

Table 2 - Children's nutritional state in the rural environment of Arambaré, according to the Height/Age indicator and the type of family property the family lives in, 2005

\begin{tabular}{|c|c|c|c|c|c|c|c|c|c|c|c|c|}
\hline \multirow{2}{*}{ H/A Index } & \multicolumn{2}{|c|}{ Total population } & \multicolumn{2}{|c|}{$\begin{array}{l}\text { Employed on Large } \\
\text { Properties }\end{array}$} & \multicolumn{2}{|c|}{$\begin{array}{l}\text { Salaried Workers on } \\
\text { Small Properties }\end{array}$} & \multicolumn{2}{|c|}{ Squatters } & \multicolumn{2}{|c|}{ Smallholding owners } & \multicolumn{2}{|c|}{$\begin{array}{l}\text { Irregular rural } \\
\text { inhabitants }\end{array}$} \\
\hline & $\mathbf{N}$ & $\%$ & $\mathbf{N}$ & $\%$ & $\mathbf{N}$ & $\%$ & $\mathbf{N}$ & $\%$ & $\mathbf{N}$ & $\%$ & $\mathbf{N}$ & $\%$ \\
\hline Serious malnutrition* & 1 & 1.3 & - & - & 1 & 33.3 & - & - & - & - & - & - \\
\hline Moderate Malnutrition* & 5 & 6.3 & - & - & - & - & 1 & 8.3 & 2 & 11.8 & 2 & 50.0 \\
\hline Slight Malnutrition & 15 & 17.5 & 7 & 15.9 & 1 & 33.3 & 2 & 16.7 & 2 & 11.8 & 2 & 50.0 \\
\hline Eutrophic & 60 & 75.0 & 37 & 84.1 & 1 & 33.3 & 9 & 75.0 & 13 & 76.5 & - & - \\
\hline Total & 80 & 100 & 44 & 100 & 3 & 100 & 12 & 100 & 17 & 100 & 4 & 100 \\
\hline
\end{tabular}

Source: ROCHA, L; SANTOS, D.L; GERHARDT, T.E; ; direct research, Arambaré, 2005

$*$ The sum of serious and moderate malnutrition ( $z$ score less than -2 ) indicates established cases of the disease, and this rate for the total population represents $7.6 \%$.

In another nutritional survey done with rural children from a squat in Minas Gerais, malnutrition in the height/age index was identical to those in Arambaré, that is, $7,6 \%{ }^{(11)}$. Based on these comparisons, it can be said that, in the rural environment of Arambaré, the proportion of chronic malnutrition is not as large as in other rural regions in the country, like in the North and Northeast; however, considering the reality of the South and South-East, where prevalence was lower, the found $7.6 \%$ stands out and deserves attention.
According to Table 3, the Weight/Age rates that indicate low weight in relation to age, but also depend on two previous indexes to characterize the problem as either acute or chronic, are also present in 4 children $(5.1 \%)$. This prevalence is high if considered that this deficit affects only $2 \%$ of children in Southern Brazil, according to the 1996 PNDS$^{(18)}$. Of these four children, one is a squatter and three of them are among the smallholding owners, one of which is seriously malnourished.

Table 3 - Children's nutritional state in the rural environment of Arambaré, according to the Weight/Age indicator and the type of family property on which the family lives, 2005

\begin{tabular}{|c|c|c|c|c|c|c|c|c|c|c|c|c|}
\hline \multirow{2}{*}{ W/A index } & \multicolumn{2}{|c|}{ Total population } & \multicolumn{2}{|c|}{$\begin{array}{l}\text { Employed on Large } \\
\text { Properties }\end{array}$} & \multicolumn{2}{|c|}{$\begin{array}{l}\text { Salaried Workers on } \\
\text { Small Properties }\end{array}$} & \multicolumn{2}{|c|}{ Squatters } & \multicolumn{2}{|c|}{ Smallholding owners } & \multicolumn{2}{|c|}{$\begin{array}{l}\text { Irregular rural } \\
\text { inhabitants }\end{array}$} \\
\hline & $\mathbf{N}$ & $\%$ & $\mathbf{N}$ & $\%$ & $\mathbf{N}$ & $\%$ & $\mathbf{N}$ & $\%$ & $\mathbf{N}$ & $\%$ & $\mathbf{N}$ & $\%$ \\
\hline Serious malnutrition* & 1 & 1.3 & - & - & - & - & - & - & 1 & 5.9 & - & - \\
\hline Moderate Malnutrition* & 3 & 3.8 & - & - & - & - & 1 & 8.3 & 2 & 11.8 & - & - \\
\hline Slight Malnutrition & 14 & 17.5 & 6 & 13.6 & 1 & 33.3 & 2 & 16.7 & 2 & 11.8 & 3 & 75.0 \\
\hline Eutrophic & 50 & 62.5 & 31 & 70.5 & 2 & 66.7 & 8 & 66.7 & 8 & 47.0 & 1 & 25.0 \\
\hline Overweight & 10 & 12.5 & 6 & 13.6 & - & - & 1 & 8.3 & 3 & 17.6 & - & - \\
\hline Obesity & 2 & 2.6 & 1 & 2.3 & - & - & - & - & 1 & 5.9 & - & - \\
\hline Total & 80 & 100 & 44 & 100 & 3 & 100 & 12 & 100 & 17 & 100 & 4 & 100 \\
\hline
\end{tabular}

Source: ROCHA, L; SANTOS, D.L; GERHARDT, T.E; direct research, Arambaré, 2005

* The sum of serious and moderate malnutrition ( $z$ score less than -2 ) indicates the established cases of the disease, and this rate for the total population represents $5.1 \%$. 
Considering every index, the malnutrition analysis for $z$ score below -2 shows that these nutritional problems do not exist among individuals employed on large properties. This result differs from those found in two studies about child nutrition in rural population.

In the first study, carried out in Rio Grand do Sul in 1982, the author proved the hypothesis that children of smallholding owners that cultivate their own land tend to have a better nutritional state than the children of rural workers, who depend on a salary to feed their families ${ }^{(13)}$. In the second study, which took place in Paraná in 1983, the authors also confirmed the hypothesis that changes in family work during the children's early life, such as going from more protective nutritional situations, like smallholding owners, to salaried rural workers, could affect children's nutritional state ${ }^{(14)}$. However, the diversity of rural contexts cannot be ignored, as well as the strategies created by the social actors to solve material and immaterial problems. Hence, in this study, the fact that most smallholder owners lived precariously without producing anything, except vegetables for their own subsistence on the property, suggests that, in this rural environment, the guarantee of salary and housing somehow interferes in the lives of rural employees, reducing children's vulnerability to malnutrition in this social group.

By analyzing the problems of nutritional excesses, it is observed there is a exceeding prevalence of overweight, considering that expected for healthy populations, since $18.8 \%$ of children in the weight/height index and $12.5 \%$ of those in the weight/age index are in this situation. Moreover, both have high percentages among individuals employed on large properties and smallholding owners. The fact that studies involving this issue mainly analyzed established obesity ( $z$ score over +2 ), it becomes difficult to establish any sort of evaluation and comparison.

Obesity has a prevalence of $1.3 \%$ and $2.5 \%$ in $\mathrm{W} / \mathrm{H}$ and $\mathrm{W} / \mathrm{A}$ indexes, respectively. Moreover, it also affects children in both types of property cited above. The prevalence of this problem in Arambaré is below the $4.9 \%$ (W/A index) found in overall Brazilian children (living in rural and urban environments) in 1996 by PNDS(18).

The presence of both nutritional problems in some types of properties raises some questions that will be pointed out to follow. However, it is not the aim of this study to arrive at conclusions or explanations for this situation, as it is a lot more complex than numbers are capable of showing. The first question raised by this situation is the hypothesis that both problems could be the product of a common cause; that is, nutritional insecurity, in which the excess weight is the result of low nutritional quality occurring because of the family's economic issues. However, on crossing the nutritional state with the socioeconomic situation in which children live, no significant statistical associations were found; that is, children's life conditions did not influence in the malnutrition or excessive weight.

In this perspective, space is given to think about the social and health inequalities present in our country, in which it is impossible to simply label the most deprived with a passively starving stereotype. In fact, another aspect to be taken into consideration is the innumerable strategies and itineraries that subjects create to solve economic problems should be taken into consideration. These individuals, due to their everyday inconstancies and daily surprises, are required to constantly renovate their repertory of choices and creativity, in order to guarantee their survival. Moreover, in this case, it involves guaranteeing nutrition in the midst of these limits and economic hardships ${ }^{(9)}$. Hence, problems can be the result of unhealthy eating habits and/or of various other aspects other than nutritional ones, which require explanations before health actions can be planned to recover children's nutritional conditions.

\section{FINAL CONSIDERATIONS}

In this article, research data analysis investigated the nutritional and contextual state of children aged under five years, living in the rural environment of Arambaré. The proposal was to show how problems associated with nutritional excess and deprivation act within the social heterogeneity that characterize the studied families.

It can be said that among the five types, and even within each one, malnutrition, overweight and obesity problems presented some variations. It should be note that the social heterogeneity marked by context diversity, regarding life forms and survival strategies, can be influencing children's unequal nutritional state behavior in its typology and, therefore, interesting questions are raised for further studies. 
Nevertheless, based on epidemiological analysis results, it is possible to affirm that considering and planning nutritional child health actions generically has limits and that these dimensions need to be rethought $^{(19)}$.

It is difficult to suppose that only one aspect will be sufficient to explain such a complex issue, like the presence or absence of nutritional problems. It is believed that daily life, each family's particularities, their protagonism or their immobility, mold different degrees of illness vulnerability and impede the construction of stagnant and repeated casual models in every context. Therefore, it is necessary to make them relevant for each reality when trying to understand malnutrition and/or obesity.

The presence of overweight in this rural context, even though insignificantly, signals the need to consider this issue as research material, as well as in public policies regarding feeding and nutritional care, especially those destined to the rural population.

Based on the social heterogeneity present in Arambaré, illustrated by the situation of each family and by the diversity of the children's nutritional problems, it becomes mandatory to understand social dynamics. This is especially true because social diversities inform how societies structure and differentiate themselves in terms of the different logics that, to a certain extent, modulate individuals' behavior and affect their health; in this particular case children's health.

It is important to emphasize that there is no intent on generalizing the study results, since it is limited to a small population in a restricted rural context. Its contribution resides in the capacity to give visibility to the diversity in the poverty situation existing in the local reality.

Although it is impossible to establish a statistical correlation between the different life situations and nutritional states, the confirmation that social strategies affect children's nutritional condition suggests that the economic indicator is not sufficient to explain the nutritional state causes, even though they obviously exert some influence. Hence, a partial analysis of the reality can be obtained if the association between poverty and nutritional state is naturalized in a linear way, based on traditional indicators like income.

\section{REFERENCES}

1. Ministério da Saúde (BR). Guia alimentar para crianças menores de 2 anos. Brasília (DF): Ministério da Saúde; 2002. 23p.

2. Barros FC, Victora CG. Epidemiologia da saúde infantil: um manual para diagnóstico comunitário. São Paulo: HUCITEC-UNICEF; 1991.

3. Monte CMG. Desnutrição: um desafio secular à nutrição infantil. J Pediatr (Rio J) 2000; 76 (Supl 3): 285-97.

4. Monteiro CA, Benicio MHD'A, Iunes RF, Gouveia NC, Cardoso MAA. Evolução da desnutrição infantil. In: Monteiro CA, editor. Velhos e novos males da saúde no Brasil: a evolução do país e das doenças. 2aed. São Paulo: HUCITECNUPENS/USP; 2000. p. 421-31.

5. Organização das Nações Unidas para a Agricultura e a Alimentação (FAO)/Organização Mundial de Saúde (OMS). Conferencia Mundial de los Alimentos. Roma: FAO; 1974.

6. Ministério da Saúde (BR), Secretaria de Atenção à Saúde. Departamento de Atenção Básica. Política Nacional de Alimentação e Nutrição. $2^{a}$ ed. Brasília (DF): Ministério da Saúde; 2003.

7. Batista M Filho, Rissin A. A transição nutricional no Brasil: tendências regionais e temporais. Cad Saúde Pública 2003; 19(Supl 1):181-91.

8. Dias M, Athayde P. Gordos e desnutridos. Rev Carta Capital 2005; 324(9):24-30.

9. Gerhardt TE. Anthropologie et santé publique: approcha interdisciplinaire. Pauvreté, situations de vie et santé au quotidin à Paranaguá, Paraná, Brésil [tese de doutorado em Antropologia Social]. Paris (FR): Université de Bordeaux 2; 2000.
10. Ferreira HS. Estado nutricional de crianças menores de dez anos residentes em invasão do "Movimento dos SemTerra", Porto Calvo, Alagoas. Cad Saúde Pública 1997; 13(1):137-39.

11. Castro TG, Campos FM, Priore SE, Coelho FMG, Campos MTFS, Franceschini SCC, et al. Saúde e nutrição de crianças de 0 a 60 meses de um assentamento de reforma agrária, Vale do Rio Doce, MG, Brasil. Rev Nutr 2004; 17(2): 167-76.

12. Veiga GV, Burlandy L. Indicadores sócio-econômicos, demográficos e estado nutricional de crianças e adolescentes em um assentamento rural do Rio de Janeiro. Cad Saúde Pública 2001; 17(6): 1465-72.

13. Victora, C.G. Desnutrição e a propriedade da terra um caso no campo. Ciênc Hoje 1986; 1(5):80.

14. Sichieri R, Moura AS, Godoy JL, Niero N, Matsumoto FN. Estado nutricional de crianças e relações de trabalho da família em uma comunidade rural do Paraná, Brasil. Cad Saúde Pública 1993; 9(Supl 1):28-35.

15. Universidade Federal do Rio Grande do Sul (UFRGS), Faculdade de Economia, Programa de Pós-Graduação em Desenvolvimento Rural. Relatório Técnico Parcial: Evolução e transformação da agricultura e desenvolvimento sustentável. Contribuições para a elaboração de políticas públicas para a "Metade Sul" do Rio Grande do Sul. Porto Alegre (RS); PGDR; 2003. 198 p. Financiamento FAPERGS. Processo no 00/7970.

16. Almeida J, Gerhardt TE, Miguel LA, Netto CGAM, Verdum $\mathrm{R}$, Beck $\mathrm{FL}$, et al. Pesquisa interdisciplinar na pós-graduação: (des) caminhos de uma experiência em andamento. Rev Bras de Pós-Graduação-CAPES 2004; 1(2):116-40. 
17. World Health Organization (WHO). Global database on child growth and malnutrition. Geneva: Nutrition Unit /WHO; 1997.

18. BEMFAM- Sociedade Civil Bem-estar Familiar no Brasil. Pesquisa Nacional sobre Demografia e Saúde 1996. Rio de Janeiro: BEMFAM; 1997.

19. Ciampone MH, Tonete VLP, Pettengill MAM, Chubaci RYS. Representações sociais da equipe de enfermagem sobre a criança desnutrida e sua família. Rev. Latino-am. Enfermagem 1999 junho;7(3):17-24. 